Jurnal

p-ISSN 2621-797X ; e-ISSN 2746-6841 DOI:10.32493

Jurnal Disrupsi Bisnis, Vol. 4, No. 4, Juli 2021 (314-326)

http://openjournal.unpam.ac.id/index.php/DRB/index

\title{
Pengaruh Lingkungan Masa Pandemik Covid 19 Terhadap Produktivitas Kerja Pegawai Pada Dinas Kependudukan Dan Pencatatan Sipil (Disdukcapil) Kota Bima
}

\author{
Dewi Anggriani ${ }^{1 *}$, Amirul Mukminin² \\ ${ }^{1,2}$ Program Studi Manajemen, STIE, Bima, Nusa Tenggara Barat,Indonesia \\ dewianggriani.stiebima@gmail.com ${ }^{1 *}$, amirul.stiebima@gmail.com ${ }^{2}$
}

Received 03 Juni 2021| Revised 15 Juni 2021 | Accepted 25 Juli 2021

*Korespondensi Penulis

\begin{abstract}
Abstrak
Pandemi covid 19 mendorong adanya kebijakan baru pada lingkungan kerja pada Dinas Kependudukan Dan Pencatatan Sipil (Disdukcapil) Kota Bima yakni hubungan rekan kerja lebih dibatasi dengan keharusan jaga jarak, adanya standar dan prosedur kerja yang semakin banyak terkait pelaksanaan protokol pencegahan covid 19 sehingga tujuan penelitian ini adalah untuk mengetahui bagaimana pengaruh lingkungan masa Pandemik Covid 19 terhadap produktivitas kerja pegawai pada Dinas Kependudukan dan Pencatatan Sipil (Disdukcapil) Kota Bima. Penelitian ini merupakan penelitian kuantitatif dengan jenis penelitian asosiatif kausal. Jumlah sampel sebanyak 36 orang diperoleh dari populasi sebanyak 71 orang. Sampel diambil dengan menggunakan purposive sampling. Variabel bebas pada penelitian ini yaitu lingkungan masa pandemik covid 19 (X) sedangkan variabel terikatnya adalah produktivita kerja kerja $(\mathrm{Y})$. Instrumen pada penelitian ini yaitu kuisioner dengan skala likert. Pengujian instrumen menggunakan uji validitas dan uji reliabilitas. Peengumpulan data dilakukan dengan metode kuisioner, wawancara dan studi pustaka. Metode analisis data menggunakan regresi linier sederhana, koefisien korelasi dan uji T. Hasil penelitian menunjukkan bahwa lingkungan masa pandemik covid 19 berpengaruh positif dan tidak signifikan terhadap produktivitas kerja pegawai pada Dinas Kependudukan Dan Pencatatan Sipil (Disdukcapil) Kota Bima. Koefisien regresi variabel Lingkungan kerja masa pandemik covid 19 menunjukkan nilai positif dan tidak signifikan pada taraf signifikansi > $\alpha$ (alpha), $(0,356>0,05)$.
\end{abstract}

Kata Kunci: Lingkungan Masa Pandemik Covid 19; Produktivitas Kerja

\section{Abstract}

The COVID-19 pandemic has prompted a new policy in the work environment at the Department of Population and Civil Registration (Disdukcapil) of the City of Bima, namely the relationship between co-workers is more limited by the need to keep distance, there are more and more standards and work procedures related to the implementation of the covid 19 prevention protocol, so the purpose of this research The purpose of this study was to find out how the environmental impact of the Covid 19 Pandemic on the work productivity of employees at the Department of Population and Civil Registration (Disdukcapil) Bima City. This research is a quantitative research with causal associative research type. The number of samples as many as 36 people obtained from a population of 71 people. Samples were taken using purposive sampling. The independent variable in this study is the environment during the covid 19 pandemic $(X)$ while the dependent variable is work productivity $(Y)$. The instrument in this study is a questionnaire with a Likert scale. Testing the instrument using validity and reliability tests. Data collection is done by using questionnaires, interviews and literature studies. The data analysis method used simple linear regression, correlation coefficient and $T$ test. The results showed that the environment during the covid 19 pandemic had a positive and insignificant effect on the work productivity of employees at the Department of Population and Civil Registration (Disdukcapil) of Bima City. The regression coefficient for the Work Environment variable during the 
COVID-19 pandemic shows a positive and insignificant value at a significance level > (alpha), (0.356 $>0.05$ ).

Keywords: Covid 19 Pandemic Environment; Work Productivity

\section{PENDAHULUAN}

Corona Virus Disease 2019 (Covid 19) menjadi pandemi global yang menyebabkan perubahan pada berbagai bidang seperti pendidikan, sosial, budaya, dan perdagangan. Banyak kebiasaan baru yang harus dilakukan setiap orang agar terhindar dari penyebaran virus ini, Pandemi covid 19 mendorong adanya kebijakan baru pada Dinas Kependudukan Dan Pencatatan Sipil (Disdukcapil) Kota Bima mengenai lingkungan kerjanya untuk menjaga social distancing ini baik bagi pegawai, maupun bagi masyarakat, adanya standar dan prosedur kerja yang semakin banyak terkait pelaksanaan protokol pencegahan covid 19. Penambahan standar dan prosedur ini diikuti dengan kejelasan tugas namun tidak ada perubahan pada sistem penghargaan. Perubahan-perubahan yang terjadi memberi dampak negatif bagi pegawai yakni sedikit perasaan terbebani. Namun kesadaran akan pentingnya kebijakan ini bagi kebaikan bersama, menjadikan dampak negatif tersebut tidak berlarut-larut. Dampak positifnya,pegawai menjadi lebih fokus dalam bekerja (tidak banyak ngobrol dengan rekan), lebih perhatian pada kesehatan diri sendiri maupun orang lain, terciptanya kebiasaan baru untuk hidup lebih sehat dan bersih. (Sutrisno, 2020) menyatakan bahwa lingkungan kerja berdampak pada kondisi serta produktivitas kerja pegawai.

Lingkungan kerja adalah keseluruhan lingkungan dimana seseorang bekerja, meliputi metode kerja dan pengaturan kerjanya (Sedarmayanti, 2012). Lingkungan kerja juga merupakan salah satu hal yang mempengaruhi pelaksanaan tugas pegawai secara optimal sehingga perlu diperhatikan, yang meliputi suasana kerja, hubungan rekan kerja, dan tersedianya fasilitas kerja (Arianto \& Kurniawan, 2020). Lingkungan kerja merupakan faktor penting dalam menciptakan kondisi yang kondusif untuk para pegawai melakukan tugasnya. Dimasa pandemik covid 19 ini para pegawai membutuhkan lingkungan kerja yang sehat, aman dan nyaman dalam bekerja. Rasa nyaman dalam bekerja akan memberikan dampak positif bagi pegawai yaitu pegawai akan merasa puas dengan lingkungan kerja yang diberikan oleh organisasi

Perubahan lingkungan kerja yang dilakukan Dinas Kependudukan Dan Pencatatan Sipil (DISDUKCAPIL) Kota Bima di masa pandemik covid 19 harus benar-benar melalui proses pengambilan keputusan dengan mempertimbangkan kenyamanan pegawai, karena jika pegawai tidak nyaman maka hasil pekerjaan tidak akan optimal dan akan menurunkan produktivitas kerja pegawai. Penurunan produktivitas kerja akan berdampak pada hasil kerja yang dicapai oleh pegawai tersebut. Faktor lingkungan kerja mempunyai keterkaitan dalam mendukung produktivitas kerja. Lingkungan kerja yang nyaman dan kondusif terlahir dari kesadaran pegawai dan pimpinan sehingga kedua pihak ini perlu menciptakan lingkungan kerja tersebut. Permasalahan yang sering dihadapi orgnaisasi / perusahaan dimasa pandemik covid 19 ini adalah produktivitas kerja pegawai yang menurun dikarenakan lingkungan kerja yang kurang nyaman akibat pandemic covid 19.

Dinas Kependudukan Dan Pencatatan Sipil (DISDUKCAPIL) Kota Bima merupakan salah satu pelaksanaan pelayanan Administrasi publik yang dibentuk untuk memberikan pelayanan yang berkualitas sesuai dengan harapan dan keinginan masyarakat Kota Bima. Setelah adanya pandemi covid 19 ini pelayanan masyarakat jadi terganggu. Pemerintah bersama kepala dinas Disdukcapil membuat kebijakan untuk menjaga keselamatan pegawai maupun masyarakat. Kebijakan yang ditetapkan terkait dengan perubahan lingkungan kerja non fisik meliputi standar dan prosedur harus menggunakan masker dan sarung tangan, tidak bersentuhan dengan rekan maupun masyarakat, mewajibkan sering cuci tangan bagi pegawai dan penyemprotan hand sanitizer pada masyarakat yang datang, membatasi masyarakat 
yang datang mengurus surat dan dokumen dan menyediakan layanan online (during) serta tidak boleh melayani masyarakat yang tidak menggunakan masker. Perubahan lingkungan kerja tersebut berdampak pada menurunnya tingkat produktivitas kerja pegawai.

Bedasarkan hasil penelitian faktor yang menjadi indikasi penyebab utama masalah ketidakpuasan kerja yang dapat mempengaruhi produktivitas kerja pegawai di masa pandemik covid 19 ini adalah masalah lingkungan kerja non fisik dan lingkungan kerja fisik. Hal ini.ditunjukan dari responden yang mengatakan bahwa penyebab utama masalah produktivitas kerja terletak pada lingkungan kerja non fisik dan lingkungan kerja fisik. Saat ini lingkungan kerja non fisik masa pandemik covid 19 mengalami penurunan. Hal ini ditunjukan prosedur kerja kurang tertata rapi, hubungan antar pegawai yang kurang harmonis, sarana dan prasarana yang disediakan dimasa pandemik covid 19 kurang mendukung para pegawai untuk lebih kreatif dalam bekerja dan standar kerja pegawai yang kurang baik di masa pandek covid 19 serta dalam berkomunikasi pemimpin kurang memperhatikan perubahan sikap bawahannya di masa pandek covid 19. Akibatnya terjadi penurunan produktivitas kerja pegawai Dinas Kependudukan Dan Pencatatan Sipil (DISDUKCAPIL) Kota Bima tersebut menjadi kesulitan dalam melakukan pekerjaan mereka.

Untuk menciptakan lingkungan kerja yang produktif di masa pandemik covid 19 memang tidak mudah salah satu cara yang perlu dilakukan pimpinan dalam menciptakan lingkungan yang nyaman dan kondusif dimasa pandemik covid 19 ini yaitu pimpinan harus berusaha membangun komunikasi yang baik antar anggota tim. Komunikasi sangat penting karena sebagai jembatan bagi para pegawai dalam membangun sebuah kerja sama yang kokoh. Bila komunikasiantar pimpinan dengan pegawai berjalan lancar maka keharmonisan tim akan terus terjaga dan hubungan semakin kuat, sehingga tidak akan sungkan untuk saling berbagi dan bahu membahu menyelesaikan semua permasalahan kerja yang ada: Hasil penelitian Meilina dan Rino Sardanto (2020) menunjukkan bahwa perubahan lingkungan non fisik di masa Pandemi Covid 19 di toserba Barokah Kota Kediri berdampak negatif dan positif.

Berdasarkan latar belakang tersebut, peneliti tertarik untuk mengetahui lebih jauh bagaimana dampak perubahan lingkungan kerja, baik lingkungan kerja fisik maupun non fisik masa pandemik yang ditetapkan pada Dinas Kependudukan Dan Pencatatan Sipil (DISDUKCAPIL) Kota Bima bagi pegawainya, dan bagaimana perubahan lingkungan kerja masa pandemik tersebut berdampak pada produktivitas kerja pegawai. Sehingga penelitian ini bertujuan untuk mengetahui dan menganalisis pengaruh lingkungan masa pandemik Covid 19 terhadap produktivitas kerja pegawai pada Dinas Kependudukan Dan Pencatatan Sipil (DISDUKCAPIL) Kota Bima

Berangkat dari fenomena di atas, faktor lingkungan kerja masa pandemik Covid 19 memiliki peranan penting dalam menunjang produktivitas kerja pegawai. Untuk itu peneliti tertarik melakukan peenelitian terhadap "Pengaruh Lingkungan Masa Pandemik Covid 19 Terhadap Produktivitas Kerja Pegawai Pada Dinas Kependudukan Dan Pencatatan Sipil (DISDUKCAPIL) Kota Bima”

\section{Lingkungan Kerja}

Lingkungan kerja adalah keseluruhan alat perkakas dan bahan yang dihadapi, lingkungan sekitarnya dimana seseorang bekerja, metode kerjanya, serta pengaturan kerjanya baik sebagai perseorangan maupun sebagai kelompok (Sedarmayanti, 2017). Lingkungan kerja merupakan salah satu faktor penting dalam menciptakan kinerja pegawai. Karena Lingkungan kerja mempunyai pengaruh langsung terhadap pegawai didalam menyelesaikan pekerjaanyang pada akhirnya akan meningkatkan kinerja oragnisasi. Menurut Sunyoto (2012) lingkungan kerja adalah segala sesuatu yang ada di sekitar para pekerja dan yang dapat mempengaruhidirinya dalam menjalankan tugas-tugas yang dibebankan. Dapat disimpulkan bahwa lingkungan kerja adalah suasana dan alat penunjuang disekitar pekerja yang dapat mempengaruhi kinerja pegawai dalam menjalankan tugas - tugas yang dibebankan.

Suatu kondisi lingkungan kerja dikatakan baik apabila pegawai dapat melaksanakan kegiatan secara optimal, sehat, aman, dan nyaman. Oleh karena itu penentuan dan penciptaan lingkungan kerja 
yang baik akan sangat menentukan keberhasilan pencapaian tujuan organisasi. Sebaliknya apabila lingkungan kerja yang tidak baik akan dapat menurunkan motivasi serta semangat kerja dan akhirnya dapat menurunkan kinerja pegawai Menurut Handoko (2014) jenis-jenis dari lingkungan kerja yaitu lingkungan kerja fisik dan lingkungan kerja non fisik.

Lingkungan Kerja Fisik merupakan semua keadaan berbentuk fisik yang terdapat di sekitar tempat kerja yang dapat mempengaruhi karyawan baik secara langsung maupun tidak langsung. Lingkungan kerja fisik dapat dibagi menjadi dua, yaitu:

a. Lingkungan kerja langsung berhubungan dengan pegawai seperti kursi, meja, dan alat kerja lainnya.

Tata ruang kerja yang sesuai metode atau cara kerja sangat mendukung terciptanya hubungan kerjasama secara emosional antar pekerja maupun pekerja dengan atasannya atau sebaliknya, serta hubungan kerja sama dalam bentuk kemudahan mobilitas pekerja untuk saling berinteraksi yang muaranya adalah optimalisasi produktivitas kerja.

b. Lingkungan perantara atau lingkungan umum dapat juga disebut dengan lingkungan kerja yang memengaruhi kondisi manusia misalnya temperatur, kelembaban, sirkulas udara, pencahayaan, kebisingan, bau tidak sedap, dan penggunaan warna pada ruangan". Rasa senang karena lingkungan kerja sehat dapat menciptakan gairah kerja pekerja lebih tinggi serta dapat menciptakan konsentrasi kerja pekerja dalam menyelesaikan pekerjaannya.

Lingkungan kerja non fisik adalah semua keadaan yang terjadi yang berkaitan dengan hubungan kerja, baik hubungan dengan atasan maupun hubungan sesama rekan kerja, ataupun hubungan dengan bawahan (Robbins, 2015). Beberapa macam lingkungan kerja yang bersifat non fisik disebutkan yaitu:

a. Perasaan aman pegawai merupakan rasa aman dari berbagai bahaya yang dapat mengancam keadaan diri pegawai

b. Loyalitas pegawai merupakan sikap pegawai untuk setia terhadap perusahaan atau organisasi maupun terhadap pekerjaan yang menjadi tanggungjawabnya

c. Kepuasan pegawai merupakan perasaan puas yang muncul dalam diri pegawai yang berkaitan dengan pelaksanaan pekerjaan. Perasaan puas ini meliputi kepuasan karena kebutuhannya terpenuhi, kebutuhan sosialnya juga dapat berjalan dengan baik, serta kebutuhan yang bersifat psikologis juga terpenuhi

d. Hubungan Kerja Dalam Kantor yaitu hubungan kerja antar pekerja dan pekerja dengan pemimpin yang akan mempengaruhi pencapaian tujuan organisasi untuk meningkatkan kepuasan kerja. Hubungan ini patut untuk dipelajari lebih teliti mengingat adanya perbedaan keinginan di semua pekerja yang terlihat dalam jalannya organisasi..

Faktor lingkungan merupakan salah satu yang harus dipertimbangkan dalam sebuah organisasi / perusahaan yang sedang beroperasi. Sunyoto (2012) menjelaskan faktor-faktor lingkungan kerja yang meliputi

a. Hubungan pegawai, Dalam hubungan pegawai ini terdapat dua hubungan yaitu hubungan sebagai individu dan hubungan sebagai kelompok.

b. Tingkat kebisingan. Lingkungan kerja yang tidak tenang atau bising akan dapat menimbulkan pengaruh yang kurang baik yaitu adanya ketidaktenangan dalam bekerja.

c. Peraturan kerja. Peraturan kerja yang baik dan jelas dapat memberikan pengaruh yang baik terhadap kepuasan dan kinerja para pegawai untuk pengembangan karier di perusahaan tersebut.

d. Penerangan. Dalam hal ini, penerangan bukanlah terbatas pada penerangan listrik, tetapi termasuk juga penerangan matahari.

e. Sirkulasi udara. Sirkulasi atau pertukaran udara yang cukup maka pertama yang harus dilakukan pengadaan ventilasi.

f. Keamanan. Lingkungan kerja dengan rasa aman akan menimbulkan ketenangan dan kenyamanan, di mana hal ini akan dapat memberikan dorongan semangat untuk bekerja 
Lingkungan kerja adalah segala yang ada di sekitar para pekerja yang dapat mempengaruhi dirinya dalam menjalankan tugas yang dibebankan (Nitisemito, 2015:183). Menurut Ginanjar (2012) menyatakan bahwa lingkungan kerja diukur melalui indikator sebagai berikut:

a. Suasana kerja

Setiap pegawai selalu menginginkan suasan kerja yang menyenangkan, suasana kerja yang nyaman itu meliputi cahaya/penerangan yang jelas, suara yang tidak bising dan tenang, keamanan di dalam bekerja. Besarnya kompensasi yang diberikan perusahaan tidak akan perpengaruh secara optimal jika suasana kerja kurang kondusif. Hal ini sesuai dengan pendapat Soedarmayanti (2012) bahwa penerangan, tingkat kebisingan (ketenangan) dan suhu ruangan sebagai indikator dari lingkungan kerja berpengaruh secara positif terhadap Produktivitas kerja pegawai.

b. Hubungan dengan rekan kerja,

Hal ini dimaksudkan hubungan dengan rekan kerja harmonis dan tanpa ada saling intrik diantara sesama rekan kerja.Salah satu faktor yang dapat mempengaruhi pegawai tetap tinggal dalam suatu organisasi adalah adanya hubungan yang harmonis diantara rekan kerja.Hubungan rekan kerja yang harmonis dan kekeluargaan merupakan salah satu faktor yang dapat mempengaruhi produktivitas kerja pegawai.

c. Tersedianya Fasilitas Kerja,

Hal ini dimaksudkan bahwa peralatan yang digunakan untuk mendukung kelancaran kerja lengkap/ mutahir. Tersedianya fasilitas kerja yang lengkap, walaupun tidak baru merupakan salah satu penunjang proses kelancaran dalam bekerja.

\section{Produktivitas Kerja}

Produktivitas kerja menurut Siagian dalam Agustin (2014) adalah kemampuan menghasilkan barang/jasa dari berbagai sumber daya dan kemampuan yang dimiliki oleh setiap pekerja/pegawai. Secara umum, produktivitas dapat diartikan sebagai kemampuan meningkatkan hasil kerja pegawai yang ditinjau dari sumber daya yang dimiliki oleh setiap masing-masing individu. Hasibuan (2015:) produktivitas kerja pegawai adalah perbandingan antara hasil yang di capai dengan peran serta tenaga kerja per satu waktu. Peran serta tenaga kerja di sini adalah penggunaan sumber daya serta efisiensi dan efektif.

Berdasarkan beberapa refrensi tersebut, dalam penelitian Agustin (2014) mengenai produktivitas kerja tersebut dapat disimpulkan bahwa produktivitas adalah meningkatnya hasil kerja yang dipengaruhi oleh kemampuan para pegawai (input) dan menghasilkan sebuah barang atau jasa (output) Manullang (2014) memberi penjelasan bahwa faktor-faktor yang dapat mempengaruhi produktivitas kerja adalah

a. Pekerjaan yang menarik

b. Upah yang baik

c. Keamanan dan perlindungan dalam pekerjaan

d. Penghayatan atas maksud dan makna pekerjaan.

e. Lingkungan atau sarana kerja yang baik.

f. Promosi dan perkembangan diri mereka sejalan dengan perkembngan organisasi.

g. Merasa terlibat dalam kegiatan-kegiatan organisasi.

h. Pengertian dan simpati atas persoalan-persoalan pribadi.

i. Kesetiaan pimpinan pada diri pekerja.

j. Disiplin kerja yang keras

Untuk mengukur produktivitas kerja, diperlukan indikator. Dimensi dari produktivitas kerja menurut Sutrisno (2016) adalah sebagai berikut :

a. Kemampuan.

Mempunyai kemampuan untuk melaksanakan tugas.Kemampuan seorang pegawai sangat bergantung pada keterampilan yang dimiliki serta profesionalisme mereka dalam bekerja 
b. Meningkatkan hasil yang dicapai yaitu berusaha untuk meningkatkan hasil yang dicapai. Hasil merupakan salah satu yang dapat dirasakan baik oleh yang mengerjakan maupun yang menikmati hasil pekerjaan tersebut.

c. Semangvat kerja merupakan usaha untuk lebih baik dari hari kemarin. Indikator ini dapat dilihat dari etos kerja dan hasil yang dicapai dalam satu hari kemudian dibandingkan dengan hari sebelumnya.

d. Pengembangan diri

Senantiasa mengembangkan diri untuk meningkatkan kemampuan kerja. Pengembangan diri dapat dilihat dengan melihat tantangan dan harapan dengan apa yang dihadapi

e. Mutu yaitu selalu berusaha untuk meningkatkan mutu lebih baik dari yang telah lalu.Mutu merupakan hasil pekerjaan yang dapat menunjukkan kualitas kerja seorang pegawai.

f. Efisiensi merupakan perbandingan antara hasil yang dicapai dengan keseluruhan sumberdaya yang digunakan.Masukan dan keluaran merupakan aspek produktivitas yang memberikan pengaruh yang cukup signifikan bagi pegawai.

\section{Pengaruh Lingkungan Kerja Terhadap Produktivitas Kerja Pegawai}

Kondisi lingkungan kerja dengan perhatian dan pembudayaan lingkungan kerja yang sehat dimasa pandemik covid 19 melalui indikator suasana kerja, indikator hubungan dengan rekan kerja tentunya memegang peranan penting terhadap baik buruknya produktivitas kerja pegawai. Bila lingkungan kerja pegawai cukup nyaman dan komunikasi antar anggota tim berjalan lancar, maka bisa dipastikan performa yang dihasilkan pun tentu akan maksimal. Namun sebaliknya, apabila lingkungan kerja pegawai dipenuhi dengan kekacauan dan diwarnai persaingan yang tidak sehat antar anggota team lebih-lebih dimasa pandemik covid 19 ini, maka yang tercipta adalah kejenuhan dari para pegawai yang pada akhirnya akan menurunkan produktivitas kerja mereka setiap harinya. Untuk menciptakan lingkungan kerja yang produktif memang tidak mudah. Butuh kontribusi langsung dari masing-masing anggota tim, agarsuasana kerja yang nyaman dan menyenangkan bisa tercipta dengan sendirinya. Hal ini perlu diperhatikan para pimpinan perusahaan, mengingat kondisi lingkungan kerja yang kondusif akan mendorong anggota di dalamnya untuk menyelesaikan tugas dengan baik.

Lingkungan kerja sangat penting dalam mempengaruhi produktivitas kerja pegawai. Lingkungan kerja adalah semua keadaan yang ada di tempat kerja yang dapat mempengaruhi pegawai baik secara langsung maupun tidak langsung selain itu lingkungan kerja merupakan suatu komunitas tempat manusia berkumpul dalam suatu keberagaman serta dalam situasi dan kondisi yang berubah-ubah, termasuk dalam kondisi pandemi covid 19 saat ini. Terciptanya lingkungan kerja yang baik dapat mempengaruhi produktivitas kerja pegawai (Sutrisno, 2016). Hasil penelitian Maludin Panjaitan (2017) yang mendukung teori di atas bahwa terdapat pengaruh positif dan signifikan lingkungan kerja terhadap produktivitas kerja pegawai. Hasil penelitian yang Restin berbeda dari Meilina dan Rino Sardanto (2020). Hasil penelitian menunjukkan bahwa perubahan lingkungan non fisik di masa Pandemi Covid 19 di toserba Barokah Kota Kediri berdampak negatif dan positif.

\section{Kerangka Berpikir}

Kerangka konseptual penelitian ini didasarkan pada landasasan teori, dimana lingkungan kerja dipandang sebagai faktor yang mampu mempengaruhi produktivitas kerja pegawai. Kondisi lingkungan kerja dengan perhatian dan pembudayaan lingkungan kerja yang sehat dimasa pandemik covid 19 melalui indikator suasana kerja, indikator hubungan dengan rekan kerja diharapkan dapat meningkatkan produktivitas kerja. Berdasarkan uraian teori dan penelitian terdahulu tersebut diatas maka dapat dibagun suatu kerangka konsep penelitian konseptual yang tergambar dalam model penelitian sebagai berikut: 


\begin{tabular}{|c|c|}
\hline $\begin{array}{c}\text { Lingkungan Kerja Masa } \\
\text { Pandemik Covid 19 } \\
(\mathrm{X})\end{array}$ & $\rightarrow \begin{array}{c}\text { Produktivitas Kerja } \\
\text { Pegawai (Y) }\end{array}$ \\
\hline
\end{tabular}

Gambar 1. Kerangka Berpikir

Dari kerangka pemikiran di atas dapat dijelaskan pengaruh langsung antara variabel lingkungan kerja dimasa pandemik covid 19 dengan variabel produktivitas yang artinya apabila lingkungan kerja dimasa pandemik covid 19 diterapkan dengan baik maka dapat meningkatkan produktivitas kerja pegawai.

\section{Hipotesis Penelitian}

Hipotesis merupakan jawaban sementara terhadap rumusan masalah penelitian, oleh karena itu jawaban yang diberikan baru didasarkan pada teori yang relevan belum didasarkan pada fakta-fakta empiris yang diperoleh melalui pengumpulan data (Sugiono, 2016). Berdasarkan landasan teori dan kerangka pikir dapat diajukan hipotesis sebagai berikut :

Ho : $\beta=0$ : Lingkungan kerja masa pandemik covid 19 tidak berpengaruh positif dan signifikan terhadap produktivitas kerja pegawai.

Ha $: \beta \neq 0$ : Lingkungan kerja masa pandemik covid 19 berpengaruh positif dan signifikan terhadap produktivitas kerja pegawai

\section{METODE}

\section{Jenis Penelitian}

Jenis penelitian ini termasuk dalam kategori penelitian asosiatif kausal. Menurut Sugiyono (2017:36) penelitian asosiatif kausal merupakan penelitian yang bertujuan untuk melihat dan mengetahui hubungan antara dua variabel atau lebih. Desain penelitian berfungsi untuk membantu melaksanakan penelitian agar dapat berjalan dengan baik. Metode analisis data yang digunakan untuk menganalisis masalah yang ada dengan metode analisis kuantitatif yang dinyatakan dalam bentuk skala numerik atau angka, seperti: data kualitatif yang diangkakan (scoring) (Suliyanto, 2018). Dalam penelitian ini sumber data diperoleh dari data primer yaitu data yang langsung penulis peroleh dari objek penelitian seperti tanggapan responden terhadap prnyataan/pertanyaan mengenai lingkungan kerja masa pandemik covid 19 dan produktivitas kerja pegawai.

\section{Populasi dan Sampel}

Populasi pada penelitian ini yaitu seluruh pegawai pada Dinas Kependudukan dan Pencatatan Sipil Kota Bima sebanyak 71 orang. Sampel pada penelitian ini adalah Pegawai Negeri Sipil (PNS) yang berjumlah 36 orang. Penentuan sampel dengan teknik purposive sampling yaitu peenentuan jumlah sampel dengan kriteria dan pertimbangan tertentu. Instrumen penelitian adalah suatu alat yang dapat digunakan untuk memperoleh, mengolah dan menginterpretasikan informasi yang diperoleh dari para responden. Instrumen pada penelitiani ini adalah kuisioner dengan menggunakan pengukuran skala likert.

\section{Uji Validitas dan Reliabilitas}

Pengujian instrumen dilakukan dengan dua jenis pengujian yaitu pengujian validitas dan pengujian reliabilitas..

a. Uji Validitas digunakan untuk mengukur sah atau validnya suatu kuesioner. Adapun kriteria pengambilan keputusan uji validitas untuk setiap pertanyaan adalah nilai corrected item total 
correlation atau nilai $r$ hitung harus berada diatas 0.30 . hal ini dikarenakan jika nilai $r$ hitung lebih kecil dari 0.30, berarti item tersebut memiliki hubungan yang lebih rendah dengan item-item pertanyaan lainnya dari pada variabel yang diteliti, sehingga item tersebut dinyatakan tidak valid (Arikunto, 2013).

b. Uji Reliabilitas dilakukan untuk mengetahui apakah hasil jawaban dari kuisioner oleh responden benar-benar stabil dalam mengukur suatu gejala atau kejadian, Instrumen yang realibel adalah instrumen yang digunakan beberapa kali untuk mengukur objek yang sama akan menghasilkan data yang sama. Adapun kriteria pengambilan keputuan untuk uji reliabilitas adalah dengan melihat nilai Cronbach Alpha untuk masing-masing variabel. Dimana suatu variabel dikatakan reliabel jika memberikan nilai CronbachAlpha $>0.60$

\section{Teknik Analisis Data}

Suatu penelitian harus dilakukan secara benar. Benar yang dimaksud mengikuti kaidah-kaidah ilmiah yang berlaku. Adapun analisis data pada penelitian yang digunakan dalam penelitian ini mencakup:

a. Analisis regresi linier sederhana bertujuan untuk mengetahui apakah suatu persamaan regresi yang dihasilkan adalah baik untuk mengestimasi nilai variabel terikat

b. Koefisien Korelasi adalah teknik untuk mengukur derajat keeratan hubungan, bukan untuk pendugaan dan peramalan

c. Koefisien determinasi $(R 2)$ pada intinya untuk mengukur seberapa jauh kemampuan viabel Lingkungan kerja masa pandemik covid 19 dalam menerangkan variasi variabel Produktivitas Kerja Pegawai. Penelitian ini menggunakan koefisien determinasi yang disesuaikan (Adjusted-R2), karena telah memperhitungkan jumlah variabel independen dalam suatu model regresi.

d. Uji Signifikan (Uji-t) digunakan untuk mengetahui pengaruh variabel Lingkungan kerja masa pandemik covid 19 dengan variabel Produktivitas Kerja Pegawai. Adapun kriteria pengukuran signifikan atau tidanya adalah sebagai berikut : Jika nilai signifikan ( $\mathrm{sig}>0,05)$, nilai t-hitung tidak signifikan dan jika nilai signifikan ( sig $<0,05$ ), nilai t-hitung signifikan

\section{HASIL DAN PEMBAHASAN}

\section{Uji Validitas dan Reliabilitas}

Uji validitas dalam penelitian ini digunakan untuk menguji kevalidan instrumen penelitian. Validitas menunjukan sejauh mana ketepatan dan kecermatan suatu alat ukur dalam melakukan fungsi alat ukurnya. Hasil Uji validitas dengan SPSS adalah sebagai berikut :

Tabel 1. Hasil Uji Validitas

\begin{tabular}{ccccc}
\hline Variabel X & Total Correlations & Korelai Batas & Variabel Y & Total Correlations \\
\hline X.1 & 0,894 & 0,300 & Y.1 & 0,505 \\
\hline X.2 & 0,905 & 0,300 & Y.2 & 0,788 \\
\hline X.3 & 0,680 & 0,300 & Y.3 & 0,928 \\
\hline X.4 & 0,741 & 0,300 & Y.4 & 0,928 \\
\hline X.5 & 0,860 & 0,300 & Y.5 & 0,730 \\
\hline X.6 & 0,529 & 0,300 & Y.6 & 0,814 \\
\hline X.7 & 0,870 & 0,300 & Y.7 & 0,928 \\
\hline X.8 & 0,894 & 0,300 & Y.8 & 0,811 \\
\hline X.9 & 0,832 & 0,300 & Y.9 & 0,730 \\
\hline X.10 & 0,537 & 0,300 & Y.10 & 0,645 \\
\hline
\end{tabular}

Sumber : Data Primer, diolah 2021 
Hasil uji validitas variabel Lingkungan Kerja Masa Pandemik Covid 19 dan variabel produktivitas kerja yang ditunjukkan pada nilai Item-Total Correlation tiap indikator lebih besar dari 0,30 artinya semua data instrumen penelitian dinyatakan valid dan dapat dianalisis lebih lanjut. Menurut Sugiyono (2014), jika nilai validitas setiap pertanyaan lebih besar dari nilai koefisien korelasi 0,30 maka butir pertanyaan dianggap sudah valid/sahih.

\section{Uji Reliabilitas}

Untuk mengukur reliabilitas instrumen dilakukan dengan menggunakan nilai koefisien cronbach 's alpha yang mendekati 1 menandakan reliabilitas dengan konsistensi yang tinggi. Hasil uji reliabilitas adalah sebagai berikut :

Tabel 2. Hasil Uji Reliabilitas

\begin{tabular}{cccc}
\hline Variabel Penelitian & Cronbach Alpha & $\begin{array}{c}\text { Cronbach Alpha yang } \\
\text { disyaratkan }\end{array}$ & Kesimpulan \\
\hline Lingkungan Masa Pandemik (X) & 0,883 & 0,600 & Reliable \\
\hline Produktivitas Kerja (Y) & 0,933 & 0,600 & Reliable
\end{tabular}

Sumber : Data Primer, diolah 2021

Hasil uji reliabilitas berdasarkan pada nilai Cronbach Alpha $(\alpha)$, menunjukkan dari masingmasing variabel lingkungan masa pandemik covid 19 sebesar 0,883 dan produktivitas kerja memiliki nilai cronbach alpha sebesar 0,933 . Dengan dmikian kedua variabel tersebut memenuhi unsur reliabilitas dengan nilai Cronbach Alpha $(\alpha)$ lebih besar dari 0,60. Dengan demikian instrumen penelitian dapat digunakan untuk analisis dan pengolahan data selanjutnya.

\section{Pengujian Hipotesis}

Pengujian hipotesis adalah untuk melakukan pengujian terhadap hipotesis yang diajukan. Penelitian ini mengajukan hipotesis mengenai Pengaruh Lingkungan Kerja Masa Pandemik Covid 19 terhadap Produktivitas Kerja Pegawai. Penelitian ini menggunakan analisis regresi liniear sederhana untuk melakukan uji hipotesis. Berikut ini adalah hasil analisis regresi liniear sederhana yang dilakukan dengan menggunakan program SPSS 23.00 for Windows.

\section{Analisis Regresi Linier Sederhana}

Hasil analisis regresi linier sederhana dengan menggunakan program SPSS 23.0 adalah sebagai berikut :

Tabel 3. Regresi Linier Sederhana

Coefficients $^{\mathrm{a}}$

\begin{tabular}{|c|c|c|c|c|c|}
\hline \multirow[b]{2}{*}{ Model } & \multicolumn{2}{|c|}{ Unstandardized Coefficients } & \multirow{2}{*}{$\begin{array}{c}\text { Standardized Coefficients } \\
\text { Beta }\end{array}$} & \multirow[b]{2}{*}{$\mathrm{T}$} & \multirow[b]{2}{*}{ Sig. } \\
\hline & B & Std. Error & & & \\
\hline $1 \quad$ (Constant) & 35.938 & 8.065 & & 4.456 & .000 \\
\hline $\mathrm{X}$ & .189 & .202 & .159 & .937 & .356 \\
\hline
\end{tabular}

a. Dependent Variable: Y

Sumber : Data Primer, diolah 2021

Berdasarkan hasil analisis regresi linier pada output SPSS di atas diketahui bahwa nilai kostanta (a) sebesar 35,938 dan nilai koefisien regresi (b) sebesar 0,189, dan dimasukkan dalam persamaan regresi sederhana sebagai berikut: $\mathrm{Y}=36.938+0,189 \mathrm{X}$.

Dari persamaan regresi linier berganda tersebut dapat diinterprestasikan sebagai berikut :

$\mathrm{a}=\quad$ Nilai konstanta sebesar 36.938 dengan tanda positif. Dengan demikian menunjukkan bahwa jika variabel independen (Lingkungan Masa Pandemik Covid 19) diasumsikan konstan, maka variabel dependen yaitu produktivitas kerja akan naik sebesar 36.938 jenjang kriteria 
$\mathrm{b}=$ Koefisien regresi variabel Lingkungan Masa Pandemik Covid 19 sebesar 0,373 artinya jika variabel independen mengalami kenaikan 1\%, maka produktivitas kerja pegawai (Y) akan mengalami peningkatan sebesar 0,373 . Koefisien bernilai positif artinya terjadi hubungan positif antara lingkungan kerja masa pandemik covid 19 dengan produktivitas kerja pegawai, semakin meningkat nilai lingkungan kerja masa pandemik covid 19 maka akan diikuti dengan peningkatan nilai produktivitas kerja pegawai.

\section{Koefisien Korelasi Product Moment}

Uji korelasi product moment digunakan untuk mencari keeratan hubungan antara variabel lingkungan kerja masa pandemik covid 19 terhadap produktivitas kerja pegawai. Hasil uji koefisien korelasi product moment adalah sebagai berikut:

Tabel 4. Koefisien Korelasi

Model Summary

\begin{tabular}{|c|c|c|c|c|}
\hline Model & $\mathrm{R}$ & R Square & Adjusted R Square & Std. Error of the Estimate \\
\hline 1 & $.159^{\mathrm{a}}$ & .025 & -.004 & 5.49960 \\
\hline
\end{tabular}

a. Predictors: (Constant), $\mathrm{X}$

Sumber : Data Primer, diolah 2021

Uji korelasi product moment yang ditujukkan pada kolom $\mathrm{R}$ dapat diketahui bahwa variabel lingkungan kerja masa pandemik covid 19, dalam penelitian ini memiliki hubungan yang rendah dengan variabel produktivitas kerja pegawai. Hal ini dapat dibuktikan dengan nilai koefisien korelasi (R) sebesar 0,159. Dari hasil tersebut menyatakan bahwa faktor lingkungan kerja yang diterapkan masa pandemik covid 19 pada Dinas Kependudukan Dan Pencatatan Sipil (Disdukcapil) Kota Bima dikategorikan pada hubungan yang sangat lemah dan berada diantara $(0,00-0,199)$.

\section{Koefisien Determinasi (R2)}

Untuk mengetahui besarnya kontribulasi pengaruh variabel bebas terhadap variabel terikat, maka dapat dilihat pada tabel berikut:

Tabel 5. Koefisien Determinasi

Model Summary

\begin{tabular}{lrrrrr} 
Model & R & R Square & Adjusted R Square & Std. Error of the Estimate \\
\hline 1 & & $.159^{\mathrm{a}}$ & .025 & -.004 & 5.49960 \\
\hline
\end{tabular}

a. Predictors: (Constant), $\mathrm{X}$

Sumber : Data Primer, diolah 2021

Hasil perhitungan $R$ square (determinasi) pada tabel output di atas yaitu sebesar 0,025. Nilai $R$ Square tersebut menunjukan bahwa kontribusi variabel lingkungan kerja yang diterapkan pada masa pandemik covid 19 dalam meningkatkan produktivitas kerja pegawai sebesar $0,25 \%$ dan sisanya sebesar 99,75\% disebabkan oleh variabel lain yang tidak termasuk dalam penelitian ini. Dengan demikian kontribusi lingkungan kerja terhadap produktivitas kerja pegawai di masa pandemik covid 19 pada Dinas Kependudukan Dan Pencatatan Sipil (Disdukcapil) Kota Bima tergolong sangat rendah.

\section{Uji Hipotesis (Uji-t)}

Pengujian uji hipotesis (Uji t) dilakukan dengan cara membandingkan nilai antara signifikansi t dengan nilai $\alpha=0,05$ sehingga dapat diketahui diterima atau tidaknya suatu hipotesis. 
Tabel 6. Uji-T

Coefficients $^{\mathrm{a}}$

\begin{tabular}{|c|c|c|c|c|c|}
\hline \multirow[b]{2}{*}{ Model } & \multicolumn{2}{|c|}{ Unstandardized Coefficients } & \multirow{2}{*}{$\begin{array}{c}\text { Standardized Coefficients } \\
\text { Beta }\end{array}$} & \multirow[t]{2}{*}{$\mathrm{T}$} & \multirow[t]{2}{*}{ Sig. } \\
\hline & B & Std. Error & & & \\
\hline $1 \quad$ (Constant) & 35.938 & 8.065 & & 4.456 & .000 \\
\hline$X$ & .189 & .202 & .159 & .937 & .356 \\
\hline
\end{tabular}

a. Dependent Variable: Y

Sumber : Data Primer, diolah 2021

Berdasarkan hasil uji signifikan diketahui bahwa variabel lingkungan kerja masa pandemik covid 19 bernilai positif dan tidak signifikan pada taraf signifikansi P-Value $0,356>0,05$, artinya lingkungan kerja masa pandemik covid 19 berpengaruh positif dan tidak signifikan terhadap produktivitas kerja pegawai. Hasil uji t menunjukkan nilai t-hitung yaitu sebesar 0,937. Dengan membandingkan nilai thitung dan nilai t-tabel dapat diketahui bahwa nilai t-hitung lebih kecil dari nilai t-tabel $(0,937<2,007)$. Sehingga hipotesis H0 diterima artinya lingkungan kerja masa pandemik covid 19 berpengaruh positif dan tidak signifikan terhadap produktivitas kerja pegawai Dinas Kependudukan Dan Pencatatan Sipil (Disdukcapil) Kota Bima.

\section{Pembahasan}

Pandemi covid 19 mendorong adanya kebijakan baru pada lingkungan kerja non fisik di Dinas Kependudukan Dan Pencatatan Sipil (Disdukcapil) Kota Bima yakni hubungan rekan kerja lebih dibatasi dengan keharusan jaga jarak, adanya standar dan prosedur kerja yang semakin banyak terkait pelaksanaan protokol pencegahan covid 19. Penambahan standar dan prosedur ini diikuti dengan kejelasan tugas namun tidak ada perubahan pada sistem penghargaan. Perubahan-perubahan yang terjadi memberi dampak negatif bagi pegawai yakni sedikit perasaan terbebani. Namun kesadaran akan pentingnya kebijakan ini bagi kebaikan bersama, menjadikan dampak negatif tersebut tidak berlarutlarut. Dampak positifnya, informan menjadi lebih fokus dalam bekerja (tidak banyak ngobrol dengan rekan), lebih perhatian pada kesehatan diri sendiri maupun orang lain, terciptanya kebiasaan baru untuk hidup lebih sehat dan bersih. Hasil ini semakin memperkuat penelitian (Sutrisno, 2020) yang menyatakan bahwa lingkungan kerja berdampak positif dan negatif pada kondisi serta produktivitas kerja pegawai.

Berdasarkan hasil tanggapan responden rata-rata pegawai / responden setuju jika lingkungan kerja yang nyaman dan kondisi lingkungan kerja dengan perhatian dan pembudayaan lingkungan kerja yang sehat dimasa pandemik covid 19 seperti tersedianya alat cuci tangan, sarung tangan, masker dan penyemprotan hand sanitizer melalui indikator suasana kerja, indikator hubungan dengan rekan kerja dan tersedianya fasilitas kerja yang memadai seperti sarana dan prasarana yang disediakan dimasa pandemik covid 19 mendukung para pegawai untuk lebih kreatif dalam bekerja serta tersedianya fasilitas kerja dimasa pandemik covid 19 seperti komputer dan jaringan internet dapat meningkatkan produktivitas dan semangat kerja pegawai.

Rata-rata skor variabel lingkungan kerja masa pandemik covid 19 berada pada nilai skor 43,44, hal ini menunjukkan bahwa rata-rata jawaban responden adalah seuju dan netral, artinya lingkungan kerja masa pandemik covid 19 yang sudah ada sekarang ini masih perlu diperbaiki agar dapat meningkatkan produktivitas kerja pegawai.Dengan kondisi lingkungan kerja ini dapat mewujudkan dan membina kerja sama yang mampu mendorong dan memanfaatkan partisipasi pegawai yang efektif dan efisien dimasa pandemik ini.

Berdasarkan tabel output SPSS menunjukkan bahwa jawaban responden yang paling banyak terhadap produktivitas kerja adalah menjawab netral dan kurang setuju, dengan total nilai rata-rata 39,72 berarti setiap pegawai kurang mendapatkan dukungan layanan untuk melaksanakan pekerjaan di masa 
pandemik covid 19. Bekerja adalah panggilan jiwa, pegawai termotivasi dalam bekerja karena sesuai dengan hati nurani. Lingkungan kantor selalu kondusif dan bersih dimasa pandemik mampu memperlancar aktifitas pekerjaan, pegawai selalu antusias dalam melakukan aktivitas pekerjaan. Dengan demikian kontribusi lingkungan kerja masa pandemik covid 19 terhadap produktivitas kerja pegawai pada Dinas Kependudukan Dan Pencatatan Sipil (Disdukcapil) Kota Bima tergolong rendah.

Lingkungan kerja adalah keseluruhan alat perkakas dan bahan yang dihadapai, lingkungan sekitarnya dimana seseorang bekerja, metode kerjanya, serta pengaturan kerjanya baik sebagai perorangan maupun sebagai kelompok. Secara garis besar, jenis lingkungan kerja terbagi menjadi dua yaitu lingkungan kerja fisik dan lingkungan kerja non fisik. Kondisi lingkungan kerja yang baik akan membuat pegawai merasa nyaman dalam bekerja. Berdasarkan hasil uji $\mathrm{t}$ diperoleh bahwa variabel lingkungan kerja masa pandemik covid 19 berpengaruh positif dan tidak signifikan terhadap produktivitas kerja. Hasil penelitian ini menunjukan nilai t-hitung yang lebih kecil dari nilai t-tabel $(0,937<2,007)$ pada taraf signifikansi P-Value 0,356>0,05. Jadi secara statistik dapat diimpulkan bahwa lingkungan kerja masa pandemik covid 19 dalam penelitian ini berpengaruh positif dan tidak signifikan terhadap produktivitas kerja pada Dinas Kependudukan Dan Pencatatan Sipil (Disdukcapil) Kota Bima. Hasil ini sejalan dengan penelitian dari Meilina dan Rino Sardanto (2020) menunjukkan bahwa perubahan lingkungan non fisik di masa Pandemi Covid 19 di toserba Barokah Kota Kediri berdampak negatif dan positif. Hasil penelitian yang berbeda yang dilakukan oleh Gufran (2012), dan Ariefiantoro (2012), yang mengungkapkan bahwa lingkungan kerja berpengaruh signifikan terhadap produktifitas kerja

\section{SIMPULAN}

Berdasarkan hasil analisis data dan pembahasan, maka dapat disimpulkan bahwa lingkungan masa pandemik covid 19 berpengaruh positif dan tidak signifikan terhadap produktivitas kerja pegawai pada Dinas Kependudukan Dan Pencatatan Sipil (Disdukcapil) Kota Bima. Koefisien regresi variabel Lingkungan kerja masa pandemik covid 19 menunjukkan nilai positif dan tidak signifikan, artinya apabila lingkungan kerja masa pandemik covid 19 ditingkatkan dengan cara membersihkan ruangan, penyediaan alat cuci tangan, pemakaian sarung tangan, masker dan penyemprotan hand sanitizer menjaga suasana kerja serta hubungan dengan rekan kerja yang baik maka dapat meningkatkan produktivitas kerja pegawai.

Saran pada Dinas Kependudukan Dan Pencatatan Sipil (Disdukcapil) Kota Bima antara lain:

a. Diperlukan adanya perhatian khusus terhadap pemeliharaan lingkungan fisik dan lingkungan non fisik dimasa pandemik covid 19 dalam rangka menunjang budaya organisasi yang bersifat membangun kelancaran dan produktivitas kerja pegawai.

b. Pada masa pandemik saat ini, social dan physical distancing membatasi waktu dan kesempatan wawancara yang optimal kepada informan. Selain itu, penelitian ini juga terkendala jumlah informan yang kurang banyak sehingga variasi tanggapan seharusnya bisa lebih beragam. Bagi penelitian selanjutnya diharapkan dapat memperdalam penelitian ini dan menambah jumlah informan yang lebih variatif serta mungkin dapat menggunakan metode penelitian serta menambah variabel bebas lainnya seperti kepemimpinan, motivasi, kepuasan kerja, kompensasi serta penempatan, sehingga akan lebih besar telihat pengaruh semua variabel bebas tersebut terhadap produktivitas kerja pegawai

\section{DAFTAR PUSTAKA}

Agustina, 2014, Pengaruh Motivasi terhadap Produktivitas Kerja Pegawai PT. Dwimitra Palma Lestari Samarinda, eJournal Administrasi Bisnis, 2014, 2 (3): 
Ariefiantoro, T, 2012. Analisis Pengaruh Kepemimpinan, Kepuasan Kerja Dan Lingkungan Kerja Fisik Terhadap Produktivitas Kerja Karyawan (Studi Kasus Karyawan Bagian Produksi PT. Sango Ceramic Indonesia).J. Dinamika Sosbud. Volume 14 Nomor 1.

Ghozali, Imam. 2016. Aplikasi Analisis Multivariete Dengan Program IBM SPSS 23 (Edisi 8). Cetakan ke VIII. Semarang : Badan Penerbit Universitas Diponegoro

Ginanjar Sigit Nursasongko, 2012, Analisis Pengaruh Kepemimpinan, Lingkungan Kerja Dan Kompensasi Terhadap Kinerja Pegawai (Studi Pada Badan Kepegawaian Daerah Kabupaten Pemalang), Skripsi Pada Program Sarjana Fakultas Ekonomika dan Bisnis Universitas Diponegoro.

Hasibuan, Malayu S.P. 2016. Manajemen Sumber Daya Manusia. Edisi Revisi. Jakarta : PT. Bumi Aksara.

Handoko, 2014. Manajemen Personalia Sumber Daya Manusia. Edisi Kedua. BPFE. Yogyakarta.

M. Manullang, 2014, Dasar-Dasar Manajemen, Yogyakarta : Gadjah Mada University Press

Maludin Panjaitan. 2017. Pengaruh Lingkungan Kerja Terhadap Produktivitas Kerja Pegawai, Jurnal Manajemen Vol 3. No. 2.

Meilina dan Rino Sardanto, 2020. Dampak Perubahan Lingkungan Kerja Non Fisik Masa Pandemi Covid-19 bagi Pegawai Toserba Barokah Kota Kediri. Jurnal Penelitian Manajemen Terapan (PENATARAN) Vol. 5 No. 1

Muhammad Gufran, 2012. Pengaruh Lingkungan Kerja dan Disiplin Kerja terhadap Produktivitas Kerja Karyawan PT. Pos Indonesia (Persero) Divisi Regional I Sumbar RIAU KEPRI, Jurnal Ekonomi dan Bisnis, Universitas Negeri Padang, Vol. 1 No. 1

Nitisemito, Alex, 2015, Manajemen Sumber Daya Manusia, Bandung : Pustaka Setia

Robbins, Stephen P., Timothy A. Judge, 2015. Perilaku Organisasi. Edisi 16. Terjemahan Ratna Saraswati dan Febriella Sirait. Jakarta: Salemba.

Sedarmayanti, 2017.Tata Kerja dan Produktivitas Kerja, Bandung : Mandar Maju

Sinungan, Mucdarsyah, 2014. Produktivitas Apa dan Bagaimana. Jakarta : Bumi Aksara

Sondang P, Siagian, 2014. Manajemen Sumber Daya Manusia, Jakarta : Bumi Aksara.

Sutrisno, H, Edy. 2016, Manajemen Sumber Daya Manusia, Jakarta : Kencana Prenada Media Group

Sunyoto, Danang. 2016. Metodologi Penelitian Akuntansi. Bandung: PT Refika Aditama.

Sutrisno, S. 2020. Analysis Of Compensation And Work Environment on Turnover Intention With Employee Satisfaction As Intervening Variable in PT . Hartono Istana Technology at Semarang. Serat Acitya - Jurnal Ilmiah UNTAG Semarang, 1 (1), 13-29.

Swandono Sinaga, 2016. Pengaruh Lingkungan Kerja Terhadap Produktivitas Kerja Pegawai (Bagian Produksi Minyak Kelapa Sawit Pt.Mitra Unggul Pusaka Segati Pelalawan Riau). JOM FISIP Vol. 3 No. 2 